\title{
Job Satisfaction Among Russian Workers
}

\author{
By: Susan J. Linz
}

William Davidson Working Paper Number 468

May 2002

revised March 2003 


\title{
Job Satisfaction Among Russian Workers
}

\author{
Susan J. Linz \\ Department of Economics \\ Michigan State University \\ 101 Marshall Hall \\ East Lansing, Michigan 48824 \\ (517) 353-7280 \\ linz@msu.edu \\ Research Fellow \\ William Davidson Institute \\ University of Michigan
}

May 2002

revised March 2003

Research for this paper was supported by a grant from the International Research \& Exchanges Board, with funds provided by the U.S. Department of State (Title VIII Program) and the National Endowment for the Humanities. None of these organizations is responsible for the views expressed. I thank Patricia Huddleston and Linda Good for allowing me to modify and use their survey instrument. 


\title{
Job Satisfaction Among Russian Workers
}

\author{
Abstract
}

Are Russian workers satisfied with their jobs? If not, why does it matter and what can be done? Empirical evidence based on studies of U.S. workers suggests that job satisfaction tends to correlate positively with labor productivity and negatively with labor turnover, both of which influence firm performance. Improving firm performance without substantially increasing costs is uppermost in the minds of many Russian managers. This paper analyzes the nature and scope of job satisfaction among Russian workers, using survey data to: (1) identify the level of job satisfaction expressed by 1,200 survey participants in response to questions about satisfaction with the job and satisfaction with the work that is done in the job; (2) investigate the variation in job satisfaction explained by differences in worker characteristics - both objective characteristics (age, gender, education, work experience, supervisory responsibilities, unemployment experience, marital status, recent change in workplace, number of jobs held at the time of the interview, for example) and subjective characteristics (attitude toward work); (3) ascertain the link between job satisfaction and select intrinsic and extrinsic job characteristics; and (4) evaluate the extent to which job satisfaction is correlated with alternative measures of organizational commitment. While endogeneity and simultaneity preclude establishing causality, these cross section data do permit evaluation of factors highly correlated with job satisfaction. The specific aim of the paper is to identify factors which increase the probability that a worker will express a high level of job satisfaction. The results will prove useful in designing effective reward structures and/or reducing turnover, as well as establishing management training programs to promote more effective teamwork.

Key Words: Russia, job satisfaction, job characteristics, organizational commitment, gender JEL Classification: J28, P23 


\section{Job Satisfaction Among Russian Workers}

Workers fared rather poorly during Russia's transition from a planned economy to a market economy (Clarke 1996 1998, Gimpel'son and Lippoldt 2001, Glinksaya and Mroz 2000, Khotkina 2001, Lehmann et al 1999, Linz 2000 2002, Raiklin 1999). For much of the past decade, falling real wages characterized many occupations, sectors and regions; unpaid wages accounted for nearly one-third of the wage bill (Goskomstat 2000). Desai and Idson (2000) provide a detailed account of "work without wages" in the 1990s, complementing existing studies of the impact of the transition on Russia's labor market (Clarke 1999, Commander and Coricelli 1995, Gimpel'son and Lippoldt 1999, Katz 1997, Linz 1995 1996, Newell and Reilly 1996, Reilly 1999, Sabirianova 1998, Standing 1996). This paper takes Russia's macroeconomic and labor market conditions as given, focusing instead on how employees perceive their job and workplace as the transition process draws to a close. In particular, the paper addresses the question: Are Russian workers satisfied with their jobs?

Why does it matter if Russian workers express a high or low level of job satisfaction? Several studies based on U.S. workers link job satisfaction to employee performance (Bagozzi 1980, Fisher 1980, Form 1973, Freeman 1978, Iffaldano and Muchinsky 1985, Kalleberg 1977, Larwood et al 1998, Lopez 1982, Miller and Monge 1986, Petty et al 1984). Finding ways to promote job satisfaction among Russian workers may enable managers, both domestic and foreign, to improve their firm's performance without incurring substantial additional costs. If, for example, job satisfaction translates into higher labor productivity or lower labor turnover among Russian workers, firms gain. In Russia's liquidity-constrained economic environment, improving firm performance without incurring additional costs appears to be uppermost in the minds of many managers (Krueger 2003, Linz 2002, Linz and Krueger 1996). Finding ways to promote job satisfaction among Russian workers may also have positive social consequences in the form of improved health and family welfare. ${ }^{1}$

\footnotetext{
${ }^{1}$ The negative consequences of Russia's transition on the population are well-documented in Braithwaite et al (1999), Clarke (1999), Demko et al (1999), Desai and Idson (2000), Field and Twigg (2000), and Standing (1996), for example. Connections between job satisfaction and overall well-being are discussed in Ensher et al (2001),
} 
Are Russian workers satisfied with their jobs? Job satisfaction generally implies a positive evaluation of work and a positive effect deriving from it; that is, a "positive emotional state resulting from the appraisal of one's job or job experiences" (Locke 1976, p. 1300). Utilizing survey data gathered from 1,200 Russian employees in summer 2000, this paper analyzes the nature and scope of job satisfaction, with the objective of identifying factors which increase the probability that a worker will express a high level of job satisfaction. The analysis focuses on four specific aims: (1) identify the level of reported job satisfaction among the participating Russian employees, using multiple measures to capture different dimensions of job satisfaction; (2) investigate the variation in job satisfaction explained by differences in worker characteristics, where worker characteristics include both objective factors (age, sex, education, work experience, for example) and subjective factors (attitude toward work); (3) ascertain the link between job satisfaction and select intrinsic and extrinsic job characteristics; and (4) evaluate the extent to which job satisfaction is correlated with alternative measures of organizational commitment. An important component of the paper is the analysis of gender and generational differences in job satisfaction response patterns, to evaluate whether results generated in studies of U.S. workers -- job satisfaction is positively correlated with age, but exhibits no correlation with gender (Hunt and Saul 1975, Janson and Martin 1982, Lorence and Mortimer 1985, Varca et al 1983, Weaver 1978) -- apply to the Russian employees participating in this project.

The paper is divided into four parts. Part 1 describes the job satisfaction measures used in this analysis, providing mean response values for each measure by occupational level, gender, and generation. The methodology used to identify factors which increase the probability that a worker will report a high level of job satisfaction is explained in Part 2. Three categories of factors are examined: objective and subjective respondent characteristics; intrinsic and extrinsic job characteristics; and degree of organizational commitment, as measured by attitudes expressed about the workplace. Appendix A contains a description of the participating 
employees. Part 3 presents the empirical results. Among participants in this survey, the probability that a worker will report a high level of job satisfaction is influenced more by subjective respondent characteristics - generally positive attitudes toward work - than by objective respondent characteristics such as gender or generation. Workers reporting high levels of job satisfaction tend to be those who have a high expectation of receiving a desired job characteristic, whether it be intrinsic (developing additional skills, learning new things, accomplishing something worthwhile) or extrinsic (pay, respect of co-workers). Positive attitudes toward the workplace tend to coincide with a high level of reported job satisfaction. As in studies of U.S. workers, gender differences are not apparent among the Russian workers participating in this survey. When significant generational differences emerge, it is the case that older workers tend to report higher levels of job satisfaction than younger workers. Part 4 offers concluding remarks.

\section{Measures of Job Satisfaction}

Since job satisfaction may refer to an employee's overall evaluation of the job or specific components or tasks associated with the job (Andrisani 1978), both dimensions are explicitly addressed in this analysis. ${ }^{2}$ The first measure of job satisfaction is derived from responses by employees to the statement: Generally speaking, I am very satisfied with this job (SATISFY1). ${ }^{3}$ Participants were asked to select a number from 1 to 5 , where $1=$ strongly disagree and $5=$ strongly agree; 3 is interpreted as a neutral response. For the purposes of this analysis, it is assumed that the higher the number selected, the greater the level of job satisfaction. A second measure, using the same format and scale, asks employees to respond to the statement: I am generally satisfied with the kind of work I do in this job (SATISFY2). A third measure attempts to capture the level of job satisfaction using a negatively-worded phrase, asking employees to respond to the statement: I frequently think of quitting this job (THNKQT). In this case, the level

\footnotetext{
${ }^{2}$ In the survey instrument, participants were given the written instruction that: "The purpose of the following section is to give you a chance to tell how you feel about your present job, what things you are satisfied with and what things you are not satisfied with." Participants were asked to "circle the appropriate answer" for five statements that follow the phrase: "On my present job, this is how I feel about ..."

${ }^{3}$ Measures of job satisfaction used in studies of U.S. workers are reported in Freeman (1978) and Petty et al (1984).
} 
of job satisfaction is assumed to be inversely related to the numerical response.

To complement direct questions, two additional measures have been used in the literature to signal job satisfaction (Janson and Martin 1982): whether one would recommend the workplace to a friend, and whether one would leave the workplace for a slightly higher income elsewhere. Participants in this survey were asked about the extent to which they agree or disagree with the following two statements: The offer of a little more money with another company would not seriously make me think of changing jobs (NOTCHGJB) and I would recommend a close friend to join this company (RECOMMEN). In both cases, participants were given a scale of 1 to 5 , where $1=$ strongly disagree and $5=$ strongly agree, with 3 interpreted as a neutral response.

Finally, in an effort to check the veracity of self-reported job satisfaction, respondents were asked to identify whether they agree or disagree, on a scale from one to five, ${ }^{4}$ with the following two statements about their co-workers: Most people on this job are very satisfied with the job (ALLSATIS) and People on this job often think of quitting (ALLQUIT). If respondents report themselves as satisfied but their co-workers as dissatisfied (or vice versa), one would treat the results somewhat differently than if the two sets of responses are similar. ${ }^{5}$

Correlation coefficients for each of these seven measures of job satisfaction are reported in Table 1. Not surprisingly, SATISFY1 and SATISFY2 are highly correlated (.7046). Moreover, a relatively strong positive correlation holds between the respondent's self-reported job satisfaction (SATISFY1, SATISFY2) and the reported perception of co-workers' satisfaction (ALLSATIS): .3229 and .3018, respectively. Similarly, THNKQT and ALLQUIT are positively correlated (.3463). The fact that THNKQT and ALLQUIT are consistently negatively correlated with the other job satisfaction measures suggests that the response patterns are congruous.

\footnotetext{
${ }^{4}$ In the questionnaire, a 1-5 scale is provided where $1=$ strongly disagree and $5=$ strongly agree.

${ }^{5}$ My concern was to protect against the possibility that workers falsely report themselves as satisfied (in an effort to protect themselves in case their supervisor gains access to the information, for example), but report their co-workers as dissatisfied in order to signal the true situation. Self-reports are considered accurate if the response patterns for these two sets of questions (about the individual, about the co-workers) are consistent. That is, if a positive correlation holds between SATISFY1 (SATISFY2) and ALLSATIS, and THNKQT and ALLQUIT, this is considered to be consistent, and therefore accurate.
} 
Are the Russian workers participating in this project satisfied with their jobs? Table 2 provides the mean response for each of the job satisfaction measures. As seen in first panel of Table 2, respondents were generally satisfied with their own job (SATISFY1) and the kind of work they do in their job (SATISFY2); mean response rates were 3.79 and 3.86, respectively. ${ }^{6}$ Indeed, more than one-third of the employees participating in the survey selected "strongly agree" when asked about their satisfaction with their job (34.7\%) and the kind of work they do at their job (36.3\%). Part of the explanation for the high level of job satisfaction expressed by the Russian workers participating in this survey may lie in the Soviet legacy of the centrality of work. If work is central to one's identity or quality of life, as was the case in the Soviet economy (Gregory and Stuart 1986), it may be culturally difficult to admit dissatisfaction. ${ }^{7}$

While participants reported themselves to be rather satisfied, they were somewhat less sanguine about their co-workers' level of job satisfaction. The fact that respondents were significantly less likely to say their co-workers were satisfied with their jobs, ALLSATIS $=2.82$, may reflect either an upward bias in the self-reported job satisfaction among the participants in this survey, or a tendency to weight expressions of dissatisfaction, or "venting," by co-workers more heavily than their own in their perceptions of job satisfaction. ${ }^{8}$ A similar pattern is found in the two statements regarding quits. Participants in this survey were statistically more likely to

\footnotetext{
${ }^{6}$ Numerous studies of U.S. workers conducted between 1958 and 1977 report response rates exceeding 80\% to a question asking participants whether they are satisfied with their job or not. See, for example, Glenn and Weaver (1982), Quinn et al (1974), Katzell (1979). About 2/3rds of the participants in this survey report themselves as satisfied with their job (that is, they selected either 4 or 5 on the scale provided).

${ }^{7}$ Strauss (1974) documents response patterns among U.S. workers indicating high levels of satisfaction, even if the job is reported as "boring." These results are associated with instances where individuals have a high stake in their job or hold their work role as central to their personal identity for whatever reason. See also Gecas (1986).

${ }^{8}$ Why is it that workers who report themselves as satisfied with their job and the work that they do in their job are surrounded by co-workers who they regard as dissatisfied? One explanation may be that discussions with coworkers may frequently focus on workplace or job complaints. While respondents' complaints may be interpreted by their co-workers as exhibiting dissatisfaction, and vice versa, when reporting about themselves, respondents report honestly that they are satisfied with their job and their work. Venting, or sharing complaints with co-workers, may be as routine in Russia as in the U.S. among individuals who find their job and the work that they do in their job to be generally satisfying. The fact that managers are significantly more likely than workers to agree that coworkers are satisfied suggests that workers may not share complaints with their supervisors. Alternatively, managers simply may not "hear" dissatisfaction expressed by their subordinates. There is certainly nothing to be gained by managers saying that their co-workers are dissatisfied, and possibly there is something to be lost.
} 
disagree with the statement that they often they think of quitting (2.11) than with the statement about the frequency that their co-workers think about quitting (2.50).

Reported levels of job satisfaction vary dramatically by occupational level (see Table 2). Among managers, mean response rates were significantly higher for SATISFY1 and SATISFY2 than for workers. ${ }^{9}$ Indeed, more than $45 \%$ of the participating managers selected "strongly agree" for both job satisfaction questions. Managers were more willing than workers to recommend the workplace to their friends (RECOMMEN) and to refuse to consider changing workplaces for the offer of more money (NOTCHGJB). Managers were significantly less likely than workers to report themselves as thinking often of quitting.

No significant gender differences emerged in response patterns for SATISFY1 and SATISFY2, nor were there gender differences in responses related to thoughts of quitting (THNKQT, ALLQUIT). ${ }^{10}$ Women participating in this survey were, however, significantly less likely than men to recommend the workplace to friends (RECOMMEN) and more likely to consider changing workplaces for the offer of more money (NOTCHGJB).

Generational differences in response patterns to job satisfaction statements were evident among the participants in this survey. As seen in Table 2, older workers (born before 1965) were significantly more satisfied with their job and their work than younger workers; older workers also thought less frequently about quitting. ${ }^{11}$ Holding age constant, participants with higher education (more than 15 years of schooling) were significantly more likely to agree with the two statements that they were satisfied with their job and satisfied with their work, and significantly more likely to strongly disagree with the statement that they often thought of quitting. ${ }^{12}$

\footnotetext{
${ }^{9}$ An OLS regression, where the job satisfaction measure is the dependent variable, and a dummy variable for manager ( $=1$ if respondent holds supervisory position, $=0$ if respondent does not supervise others) as the independent variable, is used to establish whether workers and managers respond significantly differently.

${ }^{10}$ OLS regression analysis used to determine whether significant gender differences exist in the job satisfaction measures: dummy variable $=1$ if woman $(=0$ if man $)$ is the independent variable. The lack of gender differences in reported job satisfaction is consistent with findings based on surveys of U.S. workers conducted in the 1970s (Hunt and Saul 1975, Weaver 1978).

${ }^{11}$ For more general discussion of the importance of age in explaining the level of job satisfaction, see Hunt and Saul (1975), Janson and Martin (1982) Kalleberg and Loscocco (1983), Mortimer et al (1988).

${ }^{12}$ Glenn and Weaver (1982), Lincoln and Kalleberg (1985) and Miller (1980) analyze the relationship exhibited by
} 


\section{Research Methodology: Evaluating Job Satisfaction Among Russian Workers}

What factors might increase the probability that a Russian worker will express a high level of job satisfaction? Survey data gathered from 1,200 Russian employees in summer 2000 are used to address this question. Appendix A contains a description of the sample and sample selection procedures.

The literature suggests that objective and subjective respondent characteristics are likely to influence reported levels of job satisfaction (Hulin and Smith 1965, Hunt and Saul 1975, Janson and Martin 1982, Porter and Steers 1973, Varca et al 1983, Weaver 1974 1978). The objective respondent characteristics used in this analysis include: gender (WOMAN), age $\left(\right.$ YRBORN), ${ }^{13}$ education (YREDUC),${ }^{14}$ marital status (MARRIED),${ }^{15}$ recent change in workplace (CHGJOBS), ${ }^{16}$ experience with unemployment (UNEMPLOY), ${ }^{17}$ number of jobs held at time of survey (NUMJOBS), ${ }^{18}$ and overall work experience (HOWLONG). ${ }^{19}$

Subjective respondent characteristics involve attitudes toward work in general. ${ }^{20}$ In this survey, participants were asked: whether hard work makes one a better person (BETTERPR); whether hard work leads to high productivity (WKHPROD), improved performance

U.S. workers between level of education and job satisfaction.

${ }^{13}$ YRBORN $=1$ if the respondent was born after 1964, zero otherwise.

${ }^{14}$ YREDUC $=$ number of years of schooling that respondents reported completing.

${ }^{15}$ MARRIED $=1$ if respondent is married at time that survey was completed, zero if respondent is single, widowed, or divorced.

${ }^{16}$ Respondents were asked to report the number of times that they had changed places of work in the last five years.

${ }^{17}$ Respondents were asked: In the last five years, have you been unemployed ... that is, without work for more than two weeks, when you wanted to be working? Yes $=1$.

${ }^{18}$ Respondents were asked: Including this job, how many jobs-for-pay do you currently hold? They were given the following options and instructed to select one: _ _ This is the only regular job that I have; _ Two regular jobs for pay; _ Three regular jobs for pay; _ More than three regular jobs for pay.

${ }^{19}$ Respondents were asked: How many years have you worked at this organization?

${ }^{20}$ The explanatory power of attitude toward work on the level of job satisfaction is discussed by Beynon and Blackburn (1972), Broom and Glenn (1966), Dubin and Champoux (1974), Friedlander (1966), Schuman (1971), Vroom (1964) and Warr et al (1979). 
(WKHPERFM), and doing the job well (WKHWELL); and whether a person's worth is defined mainly by how well s/he does their job (WORTH). Participants also were asked to identify the extent to which they agreed with the statements that "when the workday is finished a person should forget his job" (FORGETJB) and that the "principal purpose of a person's job is to provide a means for enjoying free time" (ENJOY). Implicit in this analysis is the assumption that positive attitudes toward work will be positively correlated with job satisfaction. It is assumed, for example, that if individuals view work generally as a drudgery or an otherwise unpleasant experience, it is unlikely that they will express a high level of job satisfaction.

Correlation coefficients for the satisfaction measures and respondent characteristics are first calculated (see Table 3), and then ordered probit regression analysis is used to evaluate the extent to which objective and subjective respondent characteristics increase the probability that a worker will express a high level of job satisfaction.

Job satisfaction among U.S. workers appears to be highly correlated with intrinsic and extrinsic job characteristics (Glick et al 1986, Glisson and Durick 1988, Hackman and Oldham 1975, Gerhart 1987, Lawler 1970). Intrinsic job characteristics are those factors which influence the perceptions or feelings of workers about themselves and their work and/or motivate workers to work harder or better. The literature identifies a number of questions which are asked in this survey to address different dimensions of intrinsic job characteristics: does the job make the individual feel good about himself/herself; does the job provide an opportunity to learn or develop skills; does the job generate for the individual a sense of accomplishment; does the individual feel a sense of freedom on the job. To the extent that these factors are important to Russian workers, one would expect to find a positive correlation between the reported level of job satisfaction and these intrinsic job characteristics. This correlation would be especially strong if workers attach a high probability to experiencing these job characteristics at their current place of employment.

In this analysis, five intrinsic job characteristics used in the Huddleston and Good survey (1999) are evaluated. The intrinsic job characteristic variables used here are constructed from responses relating to the importance of the variable and responses relating to the expectation of 
receiving that same variable. That is, participants were asked:

How important is the chance you have to do something at your job that makes you feel good about yourself as a person?

How important to you at your job is the opportunity to develop your skills and abilities?

How important to you at your job is the chance you have to learn new things?

How important to you at your job is the chance you have to accomplish something worthwhile?

How important to you is the amount of freedom you have on your job?

In each case, participants were given a scale of 1 to 5 , where $1=$ not important and $5=$ extremely important. These questions were followed by a second series of questions asking participants about the likelihood that they would experience these elements at their current workplace, where participants were once again given a five-point scale, but this time $1=$ not at all likely, and $5=$ extremely likely. The intrinsic job characteristic variables are constructed by subtracting the "likelihood" value (from the second set of questions) from the "importance" value (from the first set of questions). The underlying presumption here is that the greater the perceived likelihood of experiencing a desired characteristic, the more likely the respondent will report a high level of job satisfaction.

Extrinsic job characteristics reflect outcomes generated by performing the job: pay, promotion, job security, friendliness and respect of co-workers, praise from supervisors, for example. I expect to find a positive correlation between extrinsic job characteristics and job satisfaction.

The extrinsic job characteristics used in this analysis are constructed using responses to questions about the importance of a particular variable and responses to questions about the likelihood of receiving that same variable. In particular, the following six questions were asked of the participants in this survey:

In your job, how important to you is the amount of pay that you receive?

How important to you is the amount of job security you have?

How important to you is your chance at getting a promotion or better job within the company? 
How important to you is the respect you receive from your co-workers?

How important to you is the praise that you get from your supervisor?

How important to you at your job is the friendliness of your co-workers?

For each question, respondents were given a five-point scale, where $1=$ not important and $5=$ extremely important. A second series of questions uses the same format and scale, but asks about the likelihood of experiencing each characteristic. Subtracting the "likelihood" values from the "importance" values gives the extrinsic job characteristic variable values used in this analysis.

Table 4 reports the mean values of the intrinsic and extrinsic job characteristic variables used in this analysis. Among the participants in this survey, the biggest gap between the "importance" and "likelihood" values occurs for LEARN, FREEDOM and SKILLS among the intrinsic characteristics, and for PAY and PROMOTN among the extrinsic characteristics. As seen in Table 4, there are significant gender and generational differences in response patterns the gap between the "importance" and "likelihood" values is consistently higher for women and older workers. ${ }^{21}$ Ordered probit regression analysis is used to evaluate the extent to which these intrinsic and extrinsic job characteristics increase the probability that a worker will express a high level of job satisfaction.

Finally, this paper addresses the link between job satisfaction and organizational commitment (Mathieu and Hamel 1989, Morrison 1997, Porter et al 1974, Reichers 1985, Shore and Martin 1989). Organizational commitment, referring to the attachment to one's place of work, is used in the literature to assess the likelihood among workers of turnover, absenteeism, and improved job performance (Angel and Perry 1981, Bartol 1979, Darden et al 1989, Dunham et al 1994, Mowday et al 1979, Weiner and Vardi 1980). While causality between organizational commitment and job satisfaction has not been established, research linking job satisfaction and organizational commitment has focused on (1) evaluating the role of respondent

\footnotetext{
${ }^{21}$ OLS regression analysis using the gap variable as the dependent variable and dummy variables for gender and generation as the independent variables generated the significance test results.
} 
characteristics in determining the level and variation in each (Ensher et al 2001, Elizur and Koslowsky 2001); (2) finding ways to predict and thus reduce employee turnover (Ben-Bakr et al 1994, Hatcher 1999, Ketchand and Strawson 1998, Poznanski and Bline 1997); (3) identifying possible mechanisms to increase job performance (Putterill and Rohrer 1995, Yousef 1998); and (4) exploring differences in organization commitment measures across cultures (Ibrahim and Rue 1994, Lincoln and Kalleberg 1996, Putterill and Rohrer 1995, Yousef 1998). Here, the objective is to assess the level and variation in organizational commitment among the Russian workers participating in this survey, as well as to analyze the extent to which it influences the probability that a worker will express a high level job satisfaction.

Seven statements in the survey instrument address different dimensions of organizational commitment (see Table 5). In each case, participants were asked to indicate their level of agreement or disagreement with each statement, using a 5-point scale, where $1=$ strongly disagree and $5=$ strongly agree. In five of the seven statements, the higher the score, the greater the degree of organizational commitment. I expect that these variables will be positively correlated with the job satisfaction measures (SATISFY1, SATISFY2). Two questions (QUIT, DONOMORE) were worded in a negative way, so that the lower the score, the greater the degree of organizational commitment. These variables should be negatively correlated with the job satisfaction measures (SATISFY1, SATISFY2).

The bottom panel of Table 5 presents the mean response by occupation, gender and generation. Managers consistently exhibited a stronger degree of organizational commitment than workers. Gender differences in response patterns occur in only one instance (CONTRIB). Generational differences are more frequent - older workers tend to exhibit a stronger degree of organizational commitment than younger workers. Ordered probit regression analysis is used to identify the impact of these organizational commitment variables on the probability that a worker will express a high level of job satisfaction.

\section{Empirical results}

Does the level of reported job satisfaction vary significantly among the 1,200 Russian employees participating in this survey? Table 6 provides the ordered probit regression results 
generated from the question: to what extent do respondent characteristics influence the probability that a worker will report a high level of job satisfaction? Because of the similarity of the results across the different measures of job satisfaction, only four are reported in Table 6: SATISFY1, SATISFY2, THNKQT and RECOMMEN.

In all seven specifications, where job satisfaction measures are the dependent variable and respondent characteristics are the independent variables, subjective respondent characteristics, that is, attitudes toward work in general, were more influential than objective characteristics in explaining the probability that a worker would report a high level of job satisfaction. More specifically, in all seven specifications, the probability that a worker would report a high level of job satisfaction was greatest among those who believe that hard work makes one a better person (BETTERPR), working hard leads to high productivity (WKHPROD), working hard leads to doing my job well (WKHWELL), and who disagree with the statement that when the workday is finished, a person should forget his job and enjoy himself (FORGETJB). In two specifications, SATISFY2 and RECOMMEN, how long a respondent had worked at the company (HOWLONG) was influential, and when SATISFY2 was the measure of job satisfaction, married respondents also exhibited a higher probability of reporting themselves satisfied with the work that they do in their job. Gender was not significant in any specification. Generation emerged as significant only when ALLSATIS was used as the measure of job satisfaction.

These results suggest a number of strategies managers might pursue to increase job satisfaction among their workers, as well as strategies to avoid. In the hiring process, for example, certain "screening" questions might be asked to identify individuals who have generally positive attitudes toward work. ${ }^{22}$ Establishing measures of job "success," and then recognizing and celebrating employees who achieve these measures (picture or name posted prominently on an "award board," for example) may increase the level of job satisfaction by creating a stronger link between behavior, attitude and outcome. Managers need not target

\footnotetext{
${ }^{22}$ The questions used in this survey would not be appropriate employment screening questions, however. Potential employees would likely "strongly agree" with all, regardless of their actual beliefs.
} 
workers by gender or generation in constructing teams or devising policies to enhance job satisfaction, however.

To what extent do job characteristics influence the probability that a worker will report a high level of job satisfaction? Table 7 provides the ordered probit regression results generated from this question. Once again, only four measures of job satisfaction are presented because of the consistency in the pattern of results. As seen in Table 7, in the first, second, and fourth panels where the job satisfaction measure is positively worded, the smaller the gap between importance and likelihood values for the job characteristic variable, the greater the probability that a worker will report a high level of job satisfaction; that is, the coefficients are negative. In the third panel, where the job satisfaction measure is negatively worded, the opposite result holds. $^{23}$ More specifically, the likelihood that Russian workers will report a high level of job satisfaction appears to depend among the participants in this survey upon whether their job provides opportunities to develop skills and abilities (SKILLS), a chance to accomplish something worthwhile (ACCMPL), the possibility of receiving additional pay (PAY) and the respect of their co-workers (RESPECT).

These results suggest that to raise the level of job satisfaction among their employees, managers need to reduce the gap between the importance and likelihood values for job characteristics that involve the acquisition of skills, broadly interpreted. This might be done by implementing a job-training or apprenticeship program, or sponsoring specific training workshops. Job satisfaction is highest among workers who expect to receive additional pay for doing their job well. If financial constraints preclude pursuing this strategy, managers might consider offering release time from work (one half day, for example) in lieu of additional payment.

To what extent is the probability that Russian workers will report a high level of job satisfaction contingent upon their attitude toward their workplace? Table 8 reports the ordered

\footnotetext{
${ }^{23}$ The exception to this result is reflected in the coefficient for PRAISE, when SATISFY2 is the measure of job satisfaction - praise from supervisor (PRAISE) is not so important to the participants in this survey but they do have a high expectation of receiving it if they do their jobs well.
} 
probit regression results when measures of organizational commitment are used as the independent variables. The signs on the coefficients which are significant (PROUD, NOTCHG, GOODJOB, QUIT) are consistent with hypothesis that job satisfaction is higher among those individuals who express a positive attitude about their workplace. When RECOMMEN is the proxy for job satisfaction, a positive attitude toward the workplace, interpreted here as a strong organizational commitment, plays an even more important role in accounting for the probability that a worker will report a high level of job satisfaction. Moreover, when both the job characteristic variables and organizational commitment variables are included in a single specification, controlling for respondent characteristics, the organizational commitment variables dominate the explanation of why some workers report a high level of job satisfaction.

\section{Gender and Generational Differences}

Among the employees participating in this survey, gender differences are evident in the response patterns to a number of questions related to attitude toward work and attitude toward the workplace. Moreover, significant gender differences are evident earnings, as well as in expectations of receiving desired rewards for performing the job well. Gender differences do not, however, emerge in any explanation of the probability that a high level of job satisfaction will be reported. These results are consistent with studies conducted using U.S. workers.

Generational differences in job satisfaction are evident. Among the participants in this survey, when generational differences emerge, older workers consistently express a higher level of job satisfaction than younger workers. Once again, these results are consistent with studies conducted using U.S. workers.

\section{Conclusions}

Are Russian workers satisfied with their jobs? Using survey data collected in Moscow, Saratov, and Taganrog, from 1,200 employees in summer 2000, this paper examines the relative importance of respondent characteristics, job characteristics, and attitude toward the workplace in explaining the probability that workers will report a high level of job satisfaction. Given the complexity associated with analyzing an attitude, as opposed to a performance outcome or work- 
related behavior which is more easily observed, seven measures of job satisfaction are utilized in this paper. Two of the measures are derived from questions which asked directly about the respondent's level of job satisfaction. Three measures asked indirectly about job satisfaction by questioning the frequency that the respondent thinks about quitting, about whether the respondent would recommend the company to a friend, and about whether the respondent would change workplaces in response to offer of more money elsewhere. Two questions asked about the perceived satisfaction level of co-workers.

Regardless of the measure used, the Russian workers participating in this survey were generally satisfied with their own jobs, if somewhat less sanguine about their co-workers' level of job satisfaction. Response patterns associated with the job satisfaction measures used in this analysis varied by occupation and generation, but not by gender.

To identify factors which increase the probability that a worker will express a high level of job satisfaction, this analysis considered both objective and subjective respondent characteristics, intrinsic and extrinsic job characteristics, and attitudes expressed by respondents about their workplace. The results were robust across all seven job satisfaction measures: (1) how individuals view work in general is more important than age, gender, or other objective respondent characteristics in identifying which workers will express a high level of job satisfaction; (2) the greater the expectation that individuals will receive in their job the things that they value - opportunities to learn and develop skills, a chance to accomplish something worthwhile, additional pay, and the respect of their co-workers - the higher the probability that they will express a high level of job satisfaction; (3) the greater the degree of organizational commitment, the greater the probability that a high level of job satisfaction will be expressed. Gender differences did not emerge among the Russian employees participating in this survey. Generational differences were evident - older workers exhibited a higher level of job satisfaction than younger worker.

The results generated in this analysis suggest a number of strategies managers might pursue in order to raise job satisfaction among their workers. First, while additional pay is important - workers with high incomes were those who reported a high level of job satisfaction - 
the Russian employees participating in this survey underscored the importance of acquiring skills and opportunities to learn. Adopting reward structures tied to the development and mastery of work-related skills would likely raise job satisfaction levels. Work-related skills might be expanded to include general problem solving - how to use and interpret data, where the data might involve time, energy or material use, or customer requirements, for example - or focus instead on job-specific issues. Redesigning jobs to give workers more variety in their job tasks or more responsibility would also likely coincide with higher job satisfaction among Russian employees.

Second, the positive correlation between organizational commitment and job satisfaction suggests that policies which contribute to employees being proud of where they work or otherwise identifying in a positive way with their company will have a significant impact. Sponsoring programs in the community (meals-on-wheels for pensioners, food or clothing drive for orphanage) or advertising company policies which have local appeal (employing veterans or disabled, for example) would likely be effective, as would producing a product or service that is competitive in national or global markets.

Third, these results suggest screening in the hiring process to identify individuals who are more apt to express a high level of job satisfaction can be done using a series of questions related to attitude towards work in general.

Does the level of job satisfaction expressed by employees participating in this survey account in any substantial way for the fact that Russians work without wages? While the data collected in this survey are not strictly suited to analyzing the question of why Russians work without wages, they do suggest a number of possible explanations for this phenomenon. The first involves non-monetary rewards. Among the Russian employees participating in this survey, it was important to feel that they made a contribution to their organization - more than 55\% selected "strongly agree" to the statement about the importance of making a contribution to the organization (CONTRIB); nearly half selected "strongly agree" to the statement that they are pleased to know their work made a contribution to the good of the organization (GOODJOB). More than half disagreed with the statement that they would be unwilling to do more than their 
job description to help the organization (DONOMORE).

The Russian workers participating in this survey exhibited a positive attitude toward work, which may also help to explain why they work without wages. Two-thirds agreed with the statement that a person's worth is defined by how well they do their job (WORTH). Among these respondents, there is a strong indication that intrinsic rewards and/or the centrality of work influences their view of their job.

A third reason explanation for why Russians work without wages may relate to generational conditions. These results suggest that older workers, employees brought up in the Soviet regime, are more likely than younger workers (born after 1965) to work without wages. As a group, older workers express a higher level of job satisfaction and a lower likelihood of changing jobs or looking for alternative employment. This result holds regardless of gender and education level. If the Soviet legacy of the centrality of work remains strong, especially among workers who gained experience prior to perestroika as these data suggest, then we should find the distribution of unpaid wages to be skewed towards older workers. However, the official data are not reported in such a way as to empirically test this proposition. 
Table 1: Correlation Coefficients: Measures of Job Satisfaction

\begin{tabular}{|c|c|c|c|c|c|c|c|}
\hline & SATISFY1 & SATISFY2 & ALLSATIS & RECOMMEN & NOTCHGJB & THNKQT & ALLQUIT \\
\hline \multicolumn{8}{|c|}{ Measures of job satisfaction } \\
\hline SATISFY1 & -- & & & & & & \\
\hline SATISFY2 & .7046 & -- & & & & & \\
\hline ALLSATIS & .3229 & .3018 & -- & & & & \\
\hline RECOMMEN & .4067 & .3370 & .2685 & -- & & & \\
\hline NOTCHGJB & .2564 & .2614 & .0642 & .2682 & -- & & \\
\hline THNKQT & -.4498 & -.4559 & -.1544 & -.2998 & -.1919 & -- & \\
\hline ALLQUIT & -.2472 & -.1722 & -.2358 & -.2561 & -.0909 & .3463 & -- \\
\hline
\end{tabular}

TABLE 2: Job Satisfaction Measures: Mean Response by Occupational Level, Gender Generation

\begin{tabular}{|c|c|c|c|c|c|c|c|c|c|c|c|c|c|c|}
\hline & \multicolumn{2}{|c|}{ All } & \multicolumn{2}{|c|}{ Managers } & \multicolumn{2}{|c|}{ Workers } & \multicolumn{2}{|c|}{ Men } & \multicolumn{2}{|c|}{ Women } & \multicolumn{2}{|c|}{ Young } & \multicolumn{2}{|c|}{ Old } \\
\hline & Mean & $\mathrm{N}$ & Mean & $\mathrm{N}$ & Mean & $\mathrm{N}$ & Mean & $\mathrm{N}$ & Mean & $\mathrm{N}$ & Mean & $\mathrm{N}$ & Mean & $\mathrm{N}$ \\
\hline SATISFY1 & 3.79 & 1185 & $4.11 *$ & 122 & 3.76 & 1063 & 3.84 & 449 & 3.77 & 717 & $3.71 * *$ & 512 & 3.85 & 673 \\
\hline SATISFY2 & 3.86 & 1171 & $4.19 *$ & 121 & 3.82 & 1050 & 3.85 & 442 & 3.86 & 710 & $3.73 *$ & 507 & 3.96 & 664 \\
\hline ALLSATIS & 2.82 & 1177 & $3.05^{* *}$ & 120 & 2.79 & 1057 & 2.84 & 447 & 2.80 & 711 & 2.87 & 514 & 2.78 & 663 \\
\hline RECOMMEN & 3.27 & 1180 & $3.62 *$ & 120 & 3.23 & 1060 & $3.37 * *$ & 445 & 3.20 & 716 & 3.32 & 513 & 3.23 & 667 \\
\hline NOTCHGJB & 3.55 & 1178 & $3.84 * *$ & 122 & 3.52 & 1056 & $3.67 * *$ & 445 & 3.49 & 714 & 3.51 & 510 & 3.59 & 668 \\
\hline THNKQT & 2.11 & 1170 & $1.80^{*}$ & 122 & 2.15 & 1048 & 2.13 & 441 & 2.10 & 710 & $2.23 *$ & 508 & 2.02 & 662 \\
\hline ALLQUIT & 2.52 & 1178 & 2.39 & 120 & 2.54 & 1058 & 2.50 & 447 & 2.53 & 712 & 2.54 & 514 & 2.51 & 664 \\
\hline
\end{tabular}

*Significant at $1 \%$

**Significant at 5\%. 
Table 3: Correlation Coefficients: Job Satisfaction and Respondent Characteristics

\begin{tabular}{|c|c|c|c|c|c|c|c|}
\hline Objective Resp & SATISFY1 & SATISFY2 & ALLSATIS & RECOMMEN & NOTCHGJB & THNKQT & ALLQUIT \\
\hline $\begin{array}{l}\text { WOMAN } \\
\text { YOUNG } \\
\text { YREDUC } \\
\text { MARRIED } \\
\text { CHGJOBS } \\
\text { UNEMPLOY } \\
\text { NUMJOBS } \\
\text { HOWLONG }\end{array}$ & $\begin{array}{r}-.0289 \\
-.1090 \\
.0814 \\
.0264 \\
-.0758 \\
-.1065 \\
.0002 \\
.0755\end{array}$ & $\begin{array}{r}.0051 \\
-.1447 \\
.0811 \\
.0546 \\
-.1016 \\
-.0713 \\
-.0001 \\
.1280\end{array}$ & $\begin{array}{r}-.0142 \\
.0285 \\
.0230 \\
-.0287 \\
-.0222 \\
-.0321 \\
-.0788 \\
.0186\end{array}$ & $\begin{array}{r}-.0579 \\
.0188 \\
.0718 \\
-.0032 \\
.0319 \\
-.0275 \\
.0050 \\
-.0839\end{array}$ & $\begin{array}{r}-.0611 \\
-.0432 \\
.0522 \\
.0208 \\
-.1237 \\
-.0744 \\
-.0057 \\
.0638\end{array}$ & $\begin{array}{r}-.0118 \\
.0998 \\
-.0875 \\
-.0348 \\
.1239 \\
.1222 \\
.0455 \\
-.0764\end{array}$ & $\begin{array}{r}.0104 \\
.0372 \\
-.0679 \\
-.0460 \\
.0298 \\
.0643 \\
.0042 \\
-.0259\end{array}$ \\
\hline Subjective Rest & SATISFY1 & SATISFY2 & ALLSATIS & RECOMMEN & NOTCHGJB & THNKQT & ALLQUIT \\
\hline $\begin{array}{l}\text { BETTERPR } \\
\text { WKHPROD } \\
\text { WKHPERFM } \\
\text { WKHWELL } \\
\text { WORTH } \\
\text { FORGETJB } \\
\text { ENJOY }\end{array}$ & $\begin{array}{l}.0895 \\
.2568 \\
.1813 \\
.2312 \\
.1186 \\
-.1379 \\
-.0439\end{array}$ & $\begin{array}{l}.0607 \\
.2323 \\
.1487 \\
.2184 \\
.1367 \\
-.1313 \\
-.0117\end{array}$ & $\begin{array}{l}.1946 \\
.1596 \\
.1081 \\
.1066 \\
.0834 \\
. .0268 \\
.0064\end{array}$ & $\begin{array}{l}.1229 \\
.1811 \\
.1514 \\
.1631 \\
.1287 \\
-.1629 \\
-.0946\end{array}$ & $\begin{array}{c}.0535 \\
.0343 \\
.0480 \\
.1157 \\
.1671 \\
-.1738 \\
-.1032\end{array}$ & $\begin{array}{r}.0438 \\
-.1578 \\
-.1050 \\
-.1623 \\
-.0911 \\
.1574 \\
.0624\end{array}$ & $\begin{array}{r}.0130 \\
-.0994 \\
-.0194 \\
-.0270 \\
-.0179 \\
.0920 \\
.0488\end{array}$ \\
\hline
\end{tabular}


TABLE 4: Job Characteristics: Mean Values

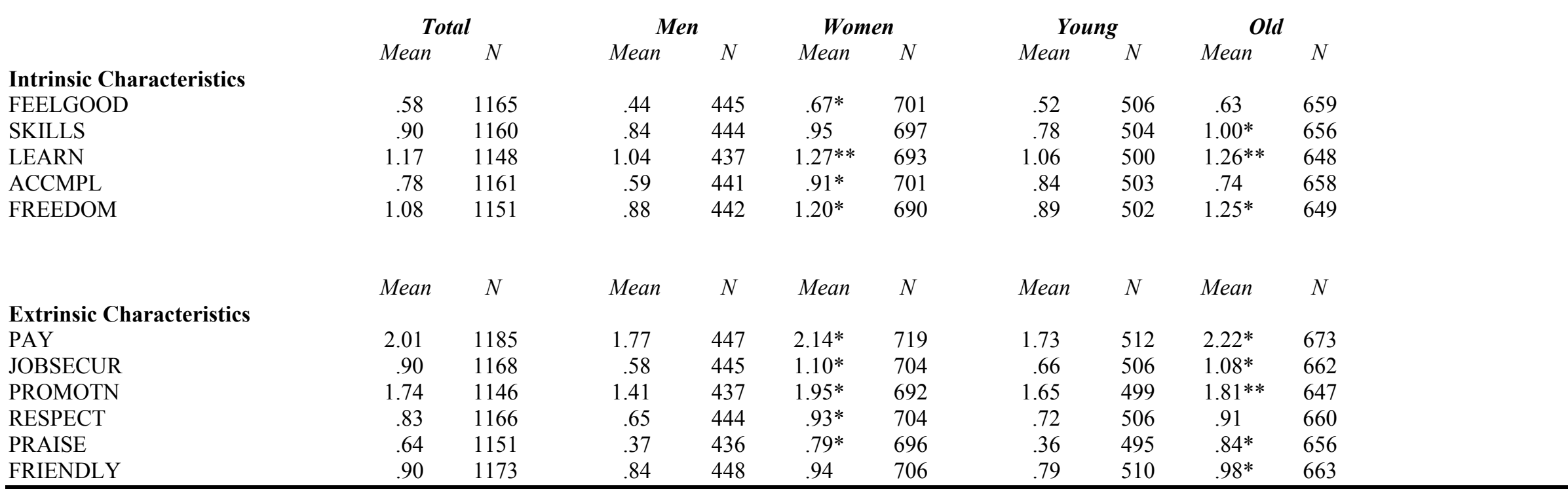

Significant @ 1\%

Significant@, 5\% 
Table 5: Measures of Organizational Commitment

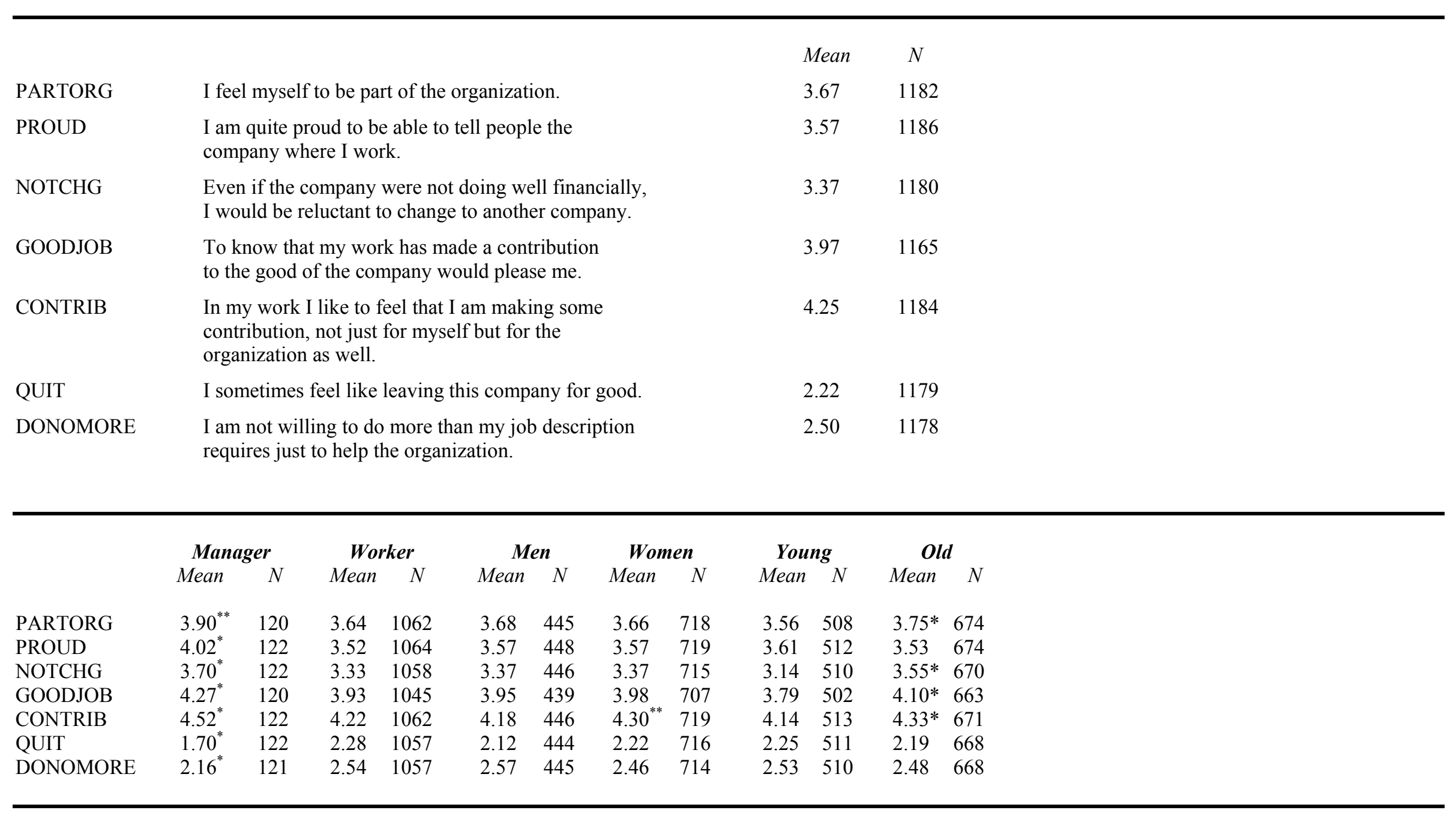

*Significant @ 1\%

**Significant @ 5\% 
Table 6: Ordered Probit Regression Results: Job Satisfaction and Respondent Characteristics

\begin{tabular}{|c|c|c|c|c|c|c|c|c|c|}
\hline & \multicolumn{2}{|c|}{ SATISFY1 } & \multicolumn{2}{|c|}{ SATISFY2 } & \multicolumn{2}{|c|}{ THNKQT } & \multicolumn{2}{|c|}{ RECOMMEN } & \\
\hline & coeff & $z$ & coeff & $z$ & coeff & $z$ & coeff & $z$ & \\
\hline WOMAN & -.0145 & -0.17 & .0746 & 0.88 & -.0180 & -0.21 & -.0454 & -0.54 & \\
\hline YRBORN & .0490 & 0.52 & .0463 & 0.49 & .0517 & 0.53 & .0314 & 0.33 & \\
\hline YREDUC & .0244 & 1.60 & .0200 & 1.30 & -.0207 & -1.29 & .0248 & 1.63 & \\
\hline MARRIED & .0971 & 1.19 & $.1990 *$ & 2.42 & -.0902 & -1.08 & .0902 & 1.12 & \\
\hline CHGJOBS & .0261 & 0.70 & -.0130 & -0.35 & .0361 & 0.94 & .0269 & 0.73 & \\
\hline UNEMPLOY & -.1443 & -1.41 & .0199 & 0.19 & .1307 & 1.24 & -.1505 & -1.47 & \\
\hline NUMJOBS & .0292 & 0.36 & -.0113 & -0.14 & .1403 & 1.69 & -.0071 & -0.09 & \\
\hline HOWLONG & .0042 & 0.89 & $.0092 * *$ & 1.91 & .0024 & 0.48 & $-.0157 *$ & -3.38 & $\sum$ \\
\hline BETTERPR & $.0748 *$ & 2.51 & $.0648 * *$ & 2.15 & $.0669 * *$ & 2.19 & $.0829 *$ & 2.84 & 气゙્ \\
\hline WKHPROD & $.2276^{*}$ & 4.94 & $.2197^{*}$ & 4.73 & $-.1265^{*}$ & -2.65 & $.1413^{*}$ & 3.08 & $\ddot{\theta}$ \\
\hline WKHPERFM & .0109 & 0.20 & .0306 & 0.57 & .0486 & 0.88 & .0428 & 0.80 & શ્ય \\
\hline WKHWELL & $.1557 *$ & 3.72 & $.1323 *$ & 3.11 & $-.1085^{*}$ & -2.50 & $.1414^{*}$ & 3.38 & $\frac{0}{\infty}$ \\
\hline WORTH & .0426 & 1.32 & .0490 & 1.51 & -.0597 & -1.79 & $.0957^{*}$ & 2.98 & $\stackrel{2}{0}$ \\
\hline FORGETJB & $-.1221 *$ & -3.93 & $-.1294 *$ & -4.13 & $.1177 * *$ & 3.62 & $-.1200^{*}$ & -3.95 & $\&$ \\
\hline \multirow[t]{2}{*}{ ENJOY } & -.0005 & -0.02 & .0324 & 1.09 & .0116 & 0.38 & -.0240 & -0.83 & 일 \\
\hline & \multicolumn{2}{|c|}{$\begin{array}{c}\mathrm{n}=846 \\
\text { pseudo } \mathrm{R}^{2}=.0522\end{array}$} & \multicolumn{2}{|c|}{$\begin{array}{c}\mathrm{n}=837 \\
\text { pseudo } \mathrm{R}^{2}=.0539\end{array}$} & \multicolumn{2}{|c|}{$\begin{array}{c}\mathrm{n}=837 \\
\text { pseudo } \mathrm{R}^{2}=.0288\end{array}$} & $\begin{array}{r}\mathrm{n}= \\
\text { pseudo }\end{array}$ & $\begin{array}{l}49 \\
2=.0437\end{array}$ & 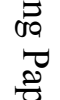 \\
\hline
\end{tabular}


Table 7: Ordered Probit Regression Results: Job Satisfaction and Job Characteristics

\begin{tabular}{|c|c|c|c|c|c|c|c|c|}
\hline & \multicolumn{2}{|c|}{ SATISFY1 } & \multicolumn{2}{|c|}{ SATISFY2 } & \multicolumn{2}{|c|}{ THNKQT } & \multicolumn{2}{|c|}{ RECOMMEN } \\
\hline & coeff & $z$ & coeff & $z$ & coeff & $z$ & coeff & $z$ \\
\hline FEELGOOD & -.0077 & -0.29 & -.0164 & -0.62 & .0143 & 0.53 & -.0312 & -1.21 \\
\hline SKILLS & $-.0915^{*}$ & -3.03 & -.0260 & -0.86 & .0102 & 0.32 & $-.0648 * *$ & -2.17 \\
\hline LEARN & -.0224 & -0.81 & -.0375 & -1.35 & $.0687 *$ & 2.41 & .0059 & 0.22 \\
\hline ACCOMPL & $-.0723 *$ & -2.56 & -.0439 & -1.54 & $.0552 * *$ & 1.89 & -.0118 & -0.42 \\
\hline FREEDOM & -.0035 & -0.15 & .0314 & 1.30 & .0136 & 0.54 & .0071 & 0.31 \\
\hline PAY & $-.0622 *$ & -2.58 & $-.0470 * *$ & -1.90 & $.0627 *$ & 2.49 & $-.0932 * *$ & -3.92 \\
\hline JOBSECUR & .0343 & 1.31 & .0198 & 0.75 & -.0113 & -0.42 & .0179 & 0.69 \\
\hline PROMOTN & -.0045 & -0.18 & -.0021 & -0.08 & -.0087 & -0.32 & -.0228 & -0.91 \\
\hline RESPECT & $-.0880 * *$ & -2.22 & $-.0812 * *$ & -2.03 & -.0073 & -0.18 & $-.0880 * *$ & -2.22 \\
\hline PRAISE & .0457 & 1.73 & $.0760 *$ & 2.85 & -.0478 & -1.74 & .0273 & 1.04 \\
\hline FRIENDLY & .0465 & 1.26 & .0316 & 0.85 & .0059 & 0.16 & .0182 & 0.50 \\
\hline & $\begin{array}{c}\mathrm{n}= \\
\text { pseudo } \mathrm{R}\end{array}$ & $\begin{array}{l}09 \\
=.0214\end{array}$ & $\begin{array}{l}\mathrm{n}=1 \\
\text { pseudo } \mathrm{R}\end{array}$ & $\begin{array}{l}00 \\
=.0103\end{array}$ & $\begin{array}{c}\mathrm{n}= \\
\text { pseudo } \mathrm{R}\end{array}$ & $\begin{array}{l}00 \\
=.0127\end{array}$ & $\begin{array}{r}\mathrm{n}= \\
\text { pseudo }\end{array}$ & $\begin{array}{l}006 \\
2=.0471\end{array}$ \\
\hline
\end{tabular}

* Significant@1\%

** Significant@5\% 
Table 8: Ordered Probit Regression Results: Job Satisfaction and Organizational Commitment

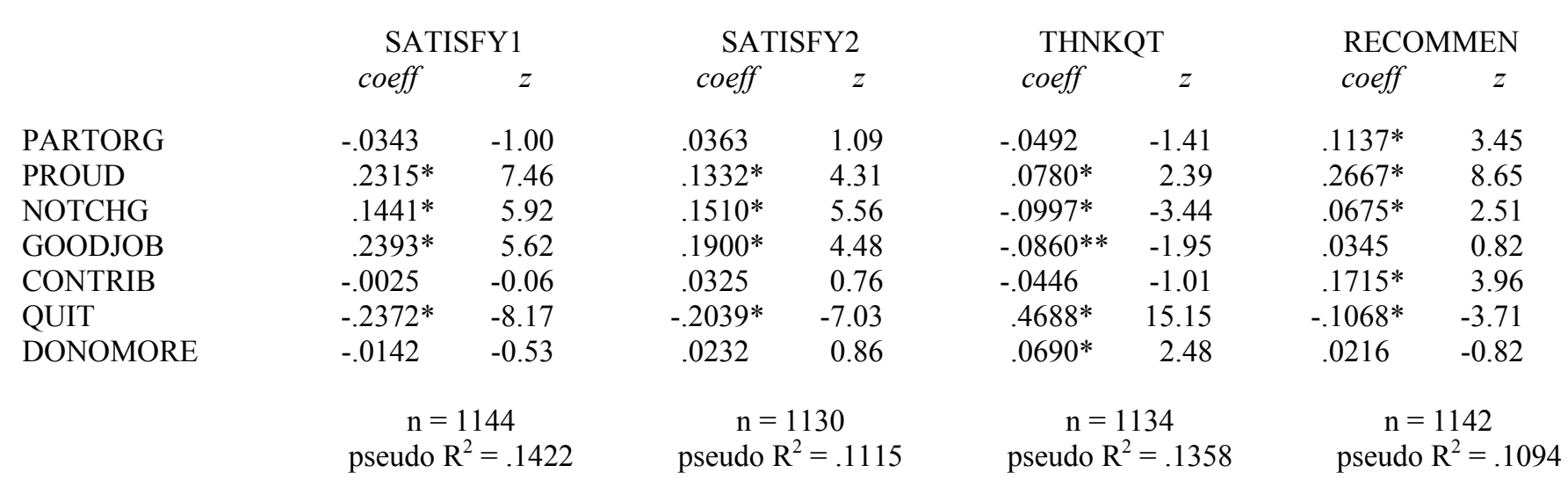

\footnotetext{
* Significant $@ 1 \%$

** Significant@5\%
} 


\section{Appendix A: Sample Description}

The survey of Russian employees was conducted in Moscow, Saratov, and Taganrog, in summer 2000. Two project coordinators in each city administered the questionnaires at each workplace, after having first secured permission to do so. ${ }^{24}$ The seventy-six participating workplaces included 35 manufacturing (heavy and light industry) organizations, 19 retail shops, 6 schools, 5 university and other institutes of higher learning, and 11 other service organizations. Project coordinators in some instances distributed questionnaires to employees in common areas of the workplace; in other instances, questionnaires were distributed in the individual shops/departments. In every instance, respondents who elected to participate were assured of anonymity and confidentiality. ${ }^{25}$ While response rates by workplace were not calculated, overall, more than $73 \%$ of the distributed questionnaires were completed.

Table A1 summarizes the basic sample characteristics. Just over $45 \%$ of the participants were located in Taganrog; some 49\% in Saratov, and nearly 6\% in Moscow. By design, workers comprised about $90 \%$ of the total number of participants.

While the mean age of the respondents was 39 years, the age distribution of the sample consists of a nearly even split between participants who were 30 years old or younger at the time the survey was conducted (28\%), between the ages of 31 and 40 years old (25\%), between the ages of 41 and 50 years old (25\%), and over 50 years old (22\%). For the purposes of this analysis, younger workers are defined as persons born after 1965. Younger workers account for $43 \%$ of the participants.

As a group, managers were significantly older than workers (44 years compared to 39 years), and earned significantly more each month (2312 rubles per month compared to 1067 rubles per month). Managers had worked at their current organization, on average, at least 14 years, compared to 10 years for workers. Managers were significantly less likely than workers to

\footnotetext{
${ }^{24}$ Since funds were not available to construct a representative sample of workplaces by city, project coordinators were instructed to contact and include as wide a variety of workplaces as possible.

${ }^{25}$ Individuals were given opportunity to take or decline taking the survey instrument. If taken, individuals had choice to return or not return the questionnaire.
} 
have reported a period of unemployment

Women account for about $62 \%$ of the respondents, and $48 \%$ of the managers participating in the survey. Women comprise a somewhat greater proportion of the older workers $(66 \%)$ than the younger workers (56\%). Women participating in this project had significantly fewer years of education and worked significantly more years at their current organization than the men participating in this project. Women, both as workers and managers, earned significantly less, on average, than their male counterparts. Women were significantly less likely than men to have reported a period of unemployment, and significantly more likely to report their marital status as divorced. $^{26}$

Average earnings varied significantly by region: in Moscow, average earnings from the respondent's primary job totaled 1722 rubles per month $(\sim 69){ }^{27}$ in Saratov, 1213 rubles $(\$ 48)$; and in Taganrog, 1087 rubles (\$43). More than $80 \%$ of those responding to the question $(n=1077)$ reported receiving $\$ 30$ or less per month from their primary job at the time the survey was conducted. ${ }^{28}$ Just under 10\% reported receiving between $\$ 30$ and $\$ 60$ per month; a similar percentage reported receiving over $\$ 60$ per month. When asked about income received per month from all jobs which the respondent held at the time of the survey: $36 \%$ reported receiving $\$ 30$ or less from all their jobs; 39\% reported receiving between $\$ 30$ and $\$ 60$ per month; $11 \%$ reported receiving between $\$ 60$ and $\$ 90$ per month; and 14\% reported receiving over $\$ 90$ per month.

In terms of work experience, nearly $20 \%$ of the participants reported working less than 2 years at their current place of employment; 47\% reported working between 2 and 10 years at their current place of employment; 15\% reported working between 11 and 20 years at their current workplace; and 19\% reported working more than 20 years at their current place of employment. Fewer than one-in-four participants responding to the question $(n=1146)$ reported experiencing a

\footnotetext{
${ }^{26}$ Just over $62 \%$ of the survey participants were married at the time the questionnaire was administered; $13 \%$ reported themselves as divorced; $21 \%$ single; and the remainder selected "widowed" or "other."

${ }^{27}$ The question asked respondents to report they monthly wage at the time. At the time, the exchange rate was approximately 25 rubles per $\$ 1$. Income categories were created to put their responses into a broader perspective.

${ }^{28}$ In many studies, absolute poverty is defined as incomes equal to \$1 per day. See for example, UNDP's Poverty in Transition (1998).
} 
William Davidson Working Paper 468

period of unemployment. 
TABLE A1: Sample Characteristics

\begin{tabular}{|c|c|c|c|c|c|c|c|c|}
\hline \multirow[t]{2}{*}{ Number of Respondents } & \multicolumn{2}{|c|}{ Moscow } & \multicolumn{2}{|l|}{ Saratov } & \multicolumn{2}{|c|}{ Taganrog } & \multicolumn{2}{|l|}{ Total } \\
\hline & Frequer & $\%$ & Frequency & $\%$ & \multicolumn{2}{|c|}{ Frequency $\%$} & Frequency & $\%$ \\
\hline Workers & 69 & 6.4 & 523 & 48.5 & 486 & 45.1 & 1078 & 100 \\
\hline Managers & 0 & 0.0 & 62 & 49.2 & 60 & 50.8 & 122 & 100 \\
\hline Men & 33 & 7.3 & 188 & 41.7 & 230 & 51.0 & 453 & 100 \\
\hline Women & 36 & 5.0 & 383 & 52.7 & 307 & 42.3 & 726 & 100 \\
\hline Younger & 19 & 1.7 & 233 & 44.7 & 269 & 51.6 & 521 & 100 \\
\hline Older & 50 & 7.4 & 352 & 51.8 & 277 & 40.8 & 679 & 100 \\
\hline Total & 69 & 5.8 & 585 & 48.8 & 546 & 45.5 & 1200 & 100 \\
\hline Respondent Characteristic & \multicolumn{2}{|c|}{ Moscow } & \multicolumn{2}{|l|}{ Saratov } & \multicolumn{2}{|c|}{ Taganrog } & \multicolumn{2}{|l|}{ Total } \\
\hline Mean Response & Mean & $\mathrm{N}$ & Mean & $\mathrm{N}$ & Mean & $\mathrm{N}$ & Mean & $\mathrm{N}$ \\
\hline Year born & 1952 & 69 & 1960 & 582 & 1963 & 528 & 1961 & 1179 \\
\hline Years of schooling & 16.3 & 65 & 15.0 & 571 & 14.9 & 534 & 15.0 & 1170 \\
\hline Income [main job] (rubles) & 1722 & 69 & 1213 & 567 & 1087 & 441 & 1194 & 1077 \\
\hline Income [all jobs] (rubles) & 2270 & 69 & 1374 & 555 & 1216 & 434 & 1368 & 1058 \\
\hline Years at current workplace & 18.8 & 69 & 11.1 & 580 & 8.6 & 530 & 10.4 & 1179 \\
\hline
\end{tabular}




\section{References}

Andrisani, Paul. 1978. "Levels and Trends in Job Satisfaction, 1966-1972," in Andrisani (ed) Work Attitudes and Labor Market Experience (New York: Praeger).

Angel, H.L and J.L. Perry. 1981. "Empirical Assessment of Organizational Commitment and Organizational Effectiveness,” vol 26 Administrative Science Quarterly, pp. 1-14.

Bagozzi, R. P. 1980. "Performance and Satisfaction in an Industrial Sales Force: An Examination of their Antecedents and Simultaneity," vol 15, no 4 Journal of Marketing pp. 65-67.

Bartol, K.M. 1979. "Professionalism as a Predictor of Organizational Commitment, Role Stress, and Turnover: A Multidimensional Approach," vol 22 Academy of Management Journal, pp. 815-821.

Ben-Bakr, Kaled, Id Al-Shammari, Omar Jefri and Jyoti Prasad. 1994. "Organizational Commitment, Satisfaction, and Turnover in Saudi Organizations: A Predictive Study,” vol 23, no 4 Journal of Socio-Economics (Winter), pp. 449-456.

Beynon, Huw and Robin Blackurn. 1972. Perceptions of Work: Variations within a Factory (Cambridge: Cambridge University Press).

Broom, Leonard and Norval Glenn. 1966. "Religious Differences in Reported Attitudes and Behavior," vol 27 Sociological Analysis (Winter), pp. 187-209.

Clarke, Simon. 1996. Labour Relations in Transition (Northampton MA: Edward Elgar).

Clarke, Simon. 1998. Structural Adjustment without Mass Unemployment (Northampton MA: Edward Elgar).

Clarke, Simon. 1999. The Formation of a Labour Market in Russia (Northampton MA: Edward Elgar).

Commander, Simon and Fabrizio Coricelli (eds).1995. Unemployment, Restructuring, and the Labor Market in Eastern Europe and Russia (Washington D.C.” World Bank).

Darden, W.R., R. Hampton and R.D. Howell. 1989. "Career Versus Organizational Commitment: Antecedents and Consequences of Retail Salespeople's Commitment," vol 65 Journal of Retailing (Spring), pp. 80-106.

Desai, Padma and Todd Idson. 2000. Work Without Wages: Russia's Nonpayment Crisis (Cambridge MA: MIT Press).

Dubin, Robert and Joseph Champoux. 1974. "Workers' Central Life Interests and Job Performance," vol 1 Sociology of Work and Occupations, pp. 313-26.

Dunham, R.B., J.A. Grube and M.B. Castaneda. 1994. "Organizational Commitment: The Utility 
of an Integrative Definition," vol 79 Journal of Applied Psychology, pp. 370-380.

Elizur, Dov and Meni Koslowsky. 2001. "Values and Organizational Commitment," vol 22, no 78 International Journal of Manpower, pp. 593-599.

Ensher, Ellen, Elisa Grant-Fallone and Stewart Donaldson. 2001. "Effects of Perceived Discrimination on Job Satisfaction, Organizational Commitment, Organizational Citizenship Behavior, and Grievances," vol 12, no 1 Human Resource Development Quarterly (Spring), pp. 53-72.

Field, Mark C and Judith L. Twigg. 2000. Russia's Torn Safety Nets (New York: St. Martin's Press).

Fisher, Cynthia. 1980. "On the Dubious Wisdom of Expecting Job Satisfaction to Correlate with Performance," Academy of Management Review vol 5, no 4 (October), pp. 607-612.

Form, William. 1973. "Auto Workers and Their Machines: A Study of Work, Factory, and Job Satisfaction in Four Countries," vol 52, no 1 Social Forces (September), pp. 1-15.

Freeman, Richard B. 1978. "Job Satisfaction as an Economic Variable," American Economic Review Papers and Proceedings, vol 68, no 2 (May), pp. 135-141.

Friedlander, F. 1966. "Importance of Work versus Nonwork Among Socially and Occupationally Stratified Groups," vol 50 Journal of Applied Psychology (December), pp. 437-441.

Gerhart, Barry. 1987. "How Important are Dispositional Factors as Determinants of Job Satisfaction?” Journal of Applied Psychology vol 72, pp 366-373.

Gimpel'son, Vladimir and Douglas Lippoldt. 1999. "Labour Turnover in Russia: Evidence from the Administrative Reporting of Enterprises in Four Regions," Transition Economics, Series No 4 (Vienna: Institute for Advanced Studies).

Gimpel'son, Vladimir and Douglas Lippoldt. 2001.The Russian Labor Market: Between Transition and Turmoil (New York: Rowman \& Littlefield Publishers).

Glenn, Noval and Charles Weaver. 1982. "Further Evidence on Education and Job Satisfaction," vol 61 Social Forces, pp. 46-55.

Glisson, Charles and Mark Durick. 1988. "Predictors of Job Satisfaction and Organizational Commitment in Human Service Organizations," Administrative Science Quarterly, vol 33, no 1 (March), pp. 61-81.

Goskomstat. 2000. Russia in Figures (Moscow).

Hatcher, Timothy. 1999. "How Multiple Interventions Influenced Employee Turnover: A Case Study," vol 10, no 4 Human Resource Development Quarterly (Winter), pp. 365-382.

Huddleston, Patricia and Linda Good. 1999. "Job Motivators in Russian and Polish Retail Firms," 
International Journal of Retail \& Distribution Management vol 27, no 9, pp. 383-392.

Hulin, C and P. Smith. 1964. “A Linear Model of Job Satisfaction,” Journal of Applied Psychology vol 48, pp. 88-92.

Hunt, John and Peter Saul. 1975. "The Relationship of Age, Tenure, and Job Satisfaction in Males and Females," Academy of Management Journal vol 18 no 4 (December), pp. 690-702.

Iaffaldano, M.T. and P.M. Muchinsky 1985. "Job Satisfaction and Job Performance: A Meta Analysis," vol 97 Psychological Bulletin , pp. 251-271.

Ibrahim, Nabil and Leslie Rue. 1994. "Organizational Commitment: Are there Differences between American and Egyptian Employees of U.S. Multinational Corporations in Egypt?” Vol 1, no 1 Journal of Transnational Management Development, pp. 23-34.

Janson, Philip and Jack Martin. 1982. "Job Satisfaction and Age: A Test of Two Views," Social Forces vol 60 no 4 (June), pp. 1089-1102.

Kalleberg, Arne. 1977. "Work Values and Job Rewards: A Theory of Job Satisfaction," American Sociological Review vol 42 no 1 (Februrary), pp. 124-143.

Kalleberg, Arne and Karen Loscocco. 1983. "Aging, Values and Rewards: Explaining Age Differences in Job Satisfaction,” vol 48 American Sociological Review, pp. 78-90.

Katz, Katarina. 1997. "Gender, Wages, and Discrimination in the USSR: A Study of a Russian Industrial Town,” Cambridge Journal of Economics vol 21, no 4 (July), pp. 431-452.

Katzell, Raymond. 1979. "Changing Attitudes Toward Work," in Clark Kerr and Jerome Rosow (eds.) Work in America: The Decade Ahead (New York: Van Nostrand Reinhold).

Ketchand Alice and Jerry Strawser. 1998. "The Existence of Multiple Measures of Organizational Commitment and Experience-Related Differences in a Public Accounting Setting," vol 10, no 1 Behavioral Research in Accounting, pp. 109-137.

Khotkina, Z. 2001. "Female Unemployment and Informal Employment in Russia," Problems of Economic Transition vol 43, no 9 (January), pp. 20-33.

Krueger, Gary. 2003. Between Two Fires: Russian Industry in Transition. (forthcoming in St. Martin's Press).

Larwood, L., Thomas Wright, Stephan Desrochers and Veronica Dahir. 1998. "Extending Latent Role and Psychological Control Theories to Predict Intent to Turnover and Politics in Business Organizations," vol 13 Group \& Organization Management (June), pp. 100123.

Lawler, Edward and Douglas Hall. 1970. "Relationship of Job Characteristics to Job Involvement, Satisfaction, and Intrinsic Motivation,” vol 54 Journal of Applied Psychology, pp. 305312. 
Lehmann, Hartmut, Jonathan Wadsworth and Alessandro Acquisiti. 1999. "Grime and Punishment: Job Insecurity and Wage Arrears in the Russian Federation,” Journal of Comparative Economics, vol 27, no 4 (December), pp. 96-133.

Lincoln, James and Arne Kalleberg. 1985. "Work Organization and Workforce Commitment: A Study of Plants and Employees in the U.S. and Japan," vol 50 American Sociological Review, pp. 738-760.

Lincoln, James and Arne Kalleberg. 1996. "Commitment, Quits, and Work Organization in Japanese and U.S. Plants,” vol 50, no 1 Industrial and Labor Relations Review (October), pp. 39-59.

Linz, Susan J. 1995. "Russian Labor Market in Transition," vol 43, no 4 Economic Development and Cultural Change (July), pp. 693-716.

Linz, Susan J. 1995. "Do Job Rights Govern Employment Patterns in Transition Economies?" American Economic Review, Papers and Proceedings, vol 85, no 2 (May), pp. 425-431.

Linz, Susan J. 1996. "Gender Differences in the Russian Labor Market," Journal of Economic Issues, vol 30, no 1 (March), pp. 161-185.

Linz, Susan J. 2000. "Labor Productivity in Russian Industry: A Regional Analysis," Economic Development and Cultural Change vol 48, no 4 (July), pp. 685-718.

Linz, Susan J. 2002. “Ownership and Employment in Russian Industry: 1992-1995,” International Journal of Manpower vol 23, no 1 (forthcoming).

Locke, Edwin. 1976. "Nature and Causes of Job Satisfaction," in Marvine Dunnette (ed) Handbook of Industrial and Organizational Psychology (Chicago: Rand McNally).

Lopez, E. "Test of the Self-Consistency Theory of the Job Performance-Job Satisfaction Relationship," Academy of Management Journal vol 25, pp. 335-348.

Lorence, Jon and Jeylan Mortimer. 1985. "Job Involvement Through the Life Course: A Panel Study of Three Age Groups," vol 50 American Sociological Review (October), pp. 618638.

Mathieu, J.E. and K. Hammel. 1989. "A Causal Model of Antecedents of Organizational Commitment Among Professionals and Nonprofessionals," vol 34 Journal of Vocational Behavior, pp. 299-317.

Miller, Katherine and Peter Monge. 1986. "Participation, Satisfaction and Productivity: A MetaAnalytic Review," Academy of Management Journal vol 29 no 4 (December) pp. 727753.

Morrison, K.A. 1997. "How Franchise Job Satisfaction and Personality Affects Performance, Organizational Commitment, Franchiser Relations, and Intention to Remain," vol 35, no 3 
Journal of Small Business Management, pp. 39-45.

Mortimer, Jeylan and Jon Lorence. 1989. "Satisfaction and Involvement: Disentangling a Deceptively Simple Relationship,” vol 52 no 4 Social Psychology Quarterly, pp. 249265.

Mowday, Richard, Lyman Porter and Richard Steers. 1982. Employee-Organization Linkages: The Psychology of Commitment, Absenteeism, and Turnover (New York: Academic Press).

Newell, Andrew and Barry Reilly. 1996. “The Gender Wage Gap in Russia: Some Empirical Evidence," Labour Economics vol 3, pp. 337-356.

Petty, M.M., GailW. McGee and Jerry W. Cavender. 1984. "A Meta Analysis of the Relationships between Individual Job Satisfaction and Individual Peformance," vol 9 Academy of Management Review, pp. 712-721.

Porter, L.W., R.M. Steers, R.T. Mowday and P.V. Boulian. 1974. "Organizational Commitment, Job Satisfaction, and Turnover among Psychiatric Technicians," vol 59 Journal of Applied Psychology, pp. 603-609.

Putterill, Martin and Thomas Rohrer. 1995. "A Causal Model of Employee Commitment in a Manufacturing Setting,” vol 15, no 5-6, International Journal of Manpower, pp. 56-69.

Quinn, Robert, Graham Staines and M.R. McCullogh. 1974. Job Satisfaction: Is there a Trend? (Washington D.C.: USGPO).

Raiklin, Ernest. 1999. "Unemployment Trands in Russia of the 1990s," International Journal of Social Economics, vol 6, no 12, pp. 1378-88.

Reichers, A.E. 1985. “A Review and Reconceptualization of Organizational Commitment," vol 10 Academy of Management, pp. 465-476.

Reilly, Barry. 1999. "The Gender Pay Gap in Russia during the Transition, 1992-1996," Economics of Transition, vol 7 no 1, pp. 245-264.

Sabirianova, Klara. 1998. "Microeconomic Analysis of Dynamic Changes in the Russian Labor Market," Problems of Economic Transition, vol 41, no 3 (July), pp. 66-88.

Schuman, Howard. 1971. "The Religious Factor in Detroit: Review, Replication and Reanalysis," vol 36 American Sociological Review, pp. 36-48.

Shore, L.M. and H.J. Martin. 1989. "Job Satisfaction and Organizational Commitment in Relation to Work Performance and Turnover Intentions," vol 42 Human Relations , pp. 625-638.

Sousa-Poza, Alfonso and Andres Sousa-Posa. 2000. "Well-Being at Work: A Cross-National Analysis of the Levels and Determinants of Job Satisfaction," vol 29 no 6 Journal of Socio-Economics, pp. 517-538. 
Standing, Guy. 1996. Russian Unemployment and Enterprise Restructuring: Reviving Dead Souls (Basingstoke: Macmillan).

Strauss, George. 1974. “Is There a Blue Collar Revolt Against Work?” in James O’Toole (ed) Work and Quality of Life (Cambridge MA: MIT Press).

Varca, Philip, Garnet Shaffer and Cynthia McCauley. 1983. "Sex Differences in Job Satisfaction Revisited," Academy of Management Journal, vol 26, no 2 (June), pp. 348-353.

Vroom, Victor. 1964. Work and Motivation (New York: Wiley).

Warr, Peter, John Cook and Toby Wall. 1979. "Scales for Measurement of Some Work Attitudes and Aspects of Psychological Well-Being," vol 52 Journal of Occupational Psychology, pp. 129-148.

Weaver, Charles. 1974. "Correlates of Job Satisfaction: Some Evidence from the National Surveys," Academy of Management Journal vol 17 no 2 (June), pp. 373-375.

Weaver, Charles. 1978. "Sex Differences in the Determinants of Job Satisfaction," Academy of Management Journal vol 21 no 2 (June), pp. 265-274.

Weiner, Y. and Y. Vardi. 1980. "Relationship between Job, Organization, and Career Commitment and Work Outcomes: An Integrative Approach," vol 26 Organizational Behavior and Human Performance, pp. 81-96.

Yousef, Darwish. 1998. "Satisfaction with Job Security as a Predictor of Organizational Commitment and Job Performance in a Multicultural Environment," vol 19, no 3 International Journal of Manpower, pp. 184-194. 


\section{DAVIDSON INSTITUTE WORKING PAPER SERIES - Most Recent Papers}

The entire Working Paper Series may be downloaded free of charge at: www.wdi.bus.umich.edu

CURRENT AS 5/22/02

\begin{tabular}{|c|c|c|}
\hline Publication & Authors & Date \\
\hline No. 468: Job Satisfaction Among Russian Workers & Susan J. Linz & May 2003 \\
\hline $\begin{array}{l}\text { No. 467: Assessing the Problem of Human Capital Mismatch in } \\
\text { Transition Economies }\end{array}$ & $\begin{array}{l}\text { Viliam Druska, Byeong ju Jeong, } \\
\text { Michal Kejak, and Viatcheslav } \\
\text { Vinogradov }\end{array}$ & Mar. 2002 \\
\hline $\begin{array}{l}\text { No. 466: Motivating Russian Workers: Analysis of Age and Gender } \\
\text { Differences }\end{array}$ & Susan J. Linz & Feb. 2002 \\
\hline No. 465: Virtual Reality: Barter and Restructuring in Russian Industry & Gary Krueger and Susan J. Linz & Apr. 2001 \\
\hline $\begin{array}{l}\text { No. 464: Lending of Last Resort, Moral Hazard and Twin Crises: } \\
\text { Lessons from the Bulgarian Financial Crisis 1996/1997 }\end{array}$ & $\begin{array}{l}\text { Michael Berlemann, Kalin } \\
\text { Hristov and Nikolay Nenovsky }\end{array}$ & May 2002 \\
\hline $\begin{array}{l}\text { No. 463: Deindustrialisation. Lessons from the Structural Outcomes of } \\
\text { Post-Communist Transition }\end{array}$ & $\begin{array}{l}\text { Tomasz Mickiewicz and Anna } \\
\text { Zalewska }\end{array}$ & Jan. 2002 \\
\hline $\begin{array}{l}\text { No. 462: Joint Liability Lending and the Rise and Fall of China's } \\
\text { Township and Village Enterprises }\end{array}$ & Albert Park and Minggao Shen & July 2001 \\
\hline $\begin{array}{l}\text { No. 461: A Refinancing Model of Decentralization with Empirical } \\
\text { Evidence from China }\end{array}$ & Albert Park and Ming & Apr. 2002 \\
\hline $\begin{array}{l}\text { No. 460: The Effects of Market Liberalization on the Relative Earnings } \\
\text { of Chinese Women }\end{array}$ & $\begin{array}{l}\text { Margaret Maurer-Fazio and } \\
\text { James Hughes }\end{array}$ & Mar. 2002 \\
\hline $\begin{array}{l}\text { No. 459: The Role of Education in Determining Labor Market } \\
\text { Outcomes in Urban China's Transitional Labor Markets }\end{array}$ & Margaret Maurer-Fazio & Apr. 2002 \\
\hline $\begin{array}{l}\text { No. 458: Real and Monetary Convergence within the European Union } \\
\text { and Between the European Union and Candidate Countries: } \\
\text { A Rolling Cointegration Approach }\end{array}$ & $\begin{array}{l}\text { Josef C. Brada, Ali M. Kutan and } \\
\text { Su Zhou }\end{array}$ & Apr. 2002 \\
\hline No. 457: Credit Ratings as Coordination Mechanisms & $\begin{array}{l}\text { Arnoud W. A. Boot and Todd T. } \\
\text { Milbourn }\end{array}$ & Mar. 2002 \\
\hline $\begin{array}{l}\text { No. 456: Balkan and Mediterranean Candidates for European Union } \\
\text { Membership: The Convergence of their Monetary Policy with that of the } \\
\text { European Central Bank }\end{array}$ & Josef C. Brada and Ali M. Kutan & Apr. 2002 \\
\hline $\begin{array}{l}\text { No. 455: Russian Financial Transition: The Development of Institutions } \\
\text { and Markets for Growth }\end{array}$ & David M. Kemme & Oct. 2001 \\
\hline $\begin{array}{l}\text { No. 454: Does the Market Pay Off? Earnings Inequality and Returns to } \\
\text { Education in Urban China }\end{array}$ & Xiaogang $\mathrm{Wu}$ and $\mathrm{Yu} \mathrm{Xie}$ & Apr. 2002 \\
\hline $\begin{array}{l}\text { No. 453: Entrepreneurs' Access to Private Equity in China: } \\
\text { The Role of Social Capital }\end{array}$ & Bat Batjargal and Mannie M. Liu & Apr. 2002 \\
\hline $\begin{array}{l}\text { No. 452: The Determinants of Privatised Enterprise Performance in } \\
\text { Russia }\end{array}$ & $\begin{array}{l}\text { Alan A. Bevan, Saul Estrin, Boris } \\
\text { Kuznetsov, Mark E. Schaffer, } \\
\text { Manuela Angelucci, Julian } \\
\text { Fennema and Giovanni } \\
\text { Mangiarotti } \\
\end{array}$ & June 2001 \\
\hline $\begin{array}{l}\text { No. 451: Determinants of Financial Distress: What Drives Bankruptcy } \\
\text { in a Transition Economy? The Czech Republic Case }\end{array}$ & Lubomír Lízal & Jan. 2002 \\
\hline No. 450: Corporate Governance and the Global Social Void & Lee A. Tavis & Oct. 2001 \\
\hline $\begin{array}{l}\text { No. 449: Financial Architecture and Economic Performance: } \\
\text { International Evidence }\end{array}$ & Solomon Tadesse & Aug. 2001 \\
\hline $\begin{array}{l}\text { No. 448: Growth Slowdown Under Central Planning: A Model of Poor } \\
\text { Incentives }\end{array}$ & Zuzana Brixiová and Aleš Bulír & Mar. 2002 \\
\hline $\begin{array}{l}\text { No. 447: Disentangling Treatment Effects of Polish Active Labor } \\
\text { Market Policies: Evidence from Matched Samples }\end{array}$ & $\begin{array}{l}\text { Jochen Kluve, Hartmut Lehmann, } \\
\text { and Christoph M. Schmidt }\end{array}$ & Jan. 2002 \\
\hline $\begin{array}{l}\text { No. 446: The Impact of Socialist Imprinting and Search for Knowledge } \\
\text { on Resource Change: An Empirical Study of Firms in Lithuania }\end{array}$ & $\begin{array}{l}\text { Aldas Kriauciunas and Prashant } \\
\text { Kale }\end{array}$ & Mar. 2002 \\
\hline $\begin{array}{l}\text { No. 445: The Costs, Wealth Effects, and Determinants of International } \\
\text { Capital Raising: Evidence from Public Yankee Bonds }\end{array}$ & $\begin{array}{l}\text { Darius P. Miller and John J. } \\
\text { Puthenpurackal }\end{array}$ & Oct. 2001 \\
\hline
\end{tabular}

